\title{
Positive EBV Test
}

National Cancer Institute

\section{Source}

National Cancer Institute. Positive EBV Test. NCI Thesaurus. Code C79122.

A laboratory test result indicating the presence of the Epstein-Barr virus in a biological sample. 